\title{
Local Economic Development Manifesto: Policy Analysis on the Implementation of Village- Owned State Enterprises
}

\author{
Ulil Afwa ${ }^{1 *}$ \\ ${ }^{1}$ Faculty of Law, Jenderal Soedirman University, Purwokerto, Indonesia
}

\begin{abstract}
Village-Owned State Enterprises have a very important role as a collective economic institution aimed at optimizing the welfare of the village community. In order to create professional Village-Owned State Enterprises management, it is important to create an active local community participation from the process of formulating, planning, to the implementation stage. Therefore it is very urgent to analyse the rules of Village-Owned State Enterprises, the existing and legal culture development of participatory community in Village-Owned State Enterprises. This paper is a Policy Analysis Exercise, a formative evaluation which aims to identify opportunities to maximize Village-Owned State Enterprises impacts by analyzing three elements of its strategic environment: public value, legitimacy and support, and operational capabilities. This research was conducted in Banyumas Regency, using sociological juridical research with qualitative research approach. The sociological juridical method used to produce policy analysis as well as to examine the legal culture that exists within society in responding to government policies and forms of participatory community legal development culture in the establishment of Village-Owned State Enterprises in Banyumas.
\end{abstract}

\section{Introduction and Literature Review}

Rural development is a part of President Joko Widodo Nawacita which is "To build Indonesia from its margins by strengthening the rural areas and villages under the framework of the Unitary Country of Republic of Indonesia”. The Village Law gives a birth to the village autonomy era where villages are required to establish Village-Owned State Enterprises to improve the village economy and develop the potential of the village. In order to create community-based economic development, one of the efforts to realize community awareness and participation in the formation of Village-Owned State Enterprises is by building a legal culture, given that legal culture is one component in the process of working the law in addition to the components of substance and structure. Legal culture is the primary factor that determines how the legal system has its logical potential in the cultural framework of the

* Corresponding author: ulilafwa25@gmail.com 
public [1]. In the formation of this legal culture also needs to be built communication and legal participation in society because this is the initial stage in building legal behaviour [2].

The main problem of the village community is poverty which influences the legal culture, because poverty can have a big impact on the possibility of a negative meaning on the values, views, ideas and behaviours that are built in the village community. It is urgent to develop a positive and constructive direction to the community's legal culture. The development of this legal culture should be built and formed based on substantial behaviour because to build and maintain society, the trust and cooperation are needed [3].

Village communities in Indonesia are transitional societies [4]. The word 'transition' itself refers to a stage of time between a certain past and a predicted future condition. In other words, in this case, the transition society is a society that is changing to a new value. The nature of society in developing countries is a transitional society, which is between people who have traditional as well as modern characteristics. Fred W. Riggs places the transition phase in the development of a society as a prismatic society which, when drawn in a linear line, lies between what is called a fused society model as a traditional society and a diffracted society for a modern society [5].

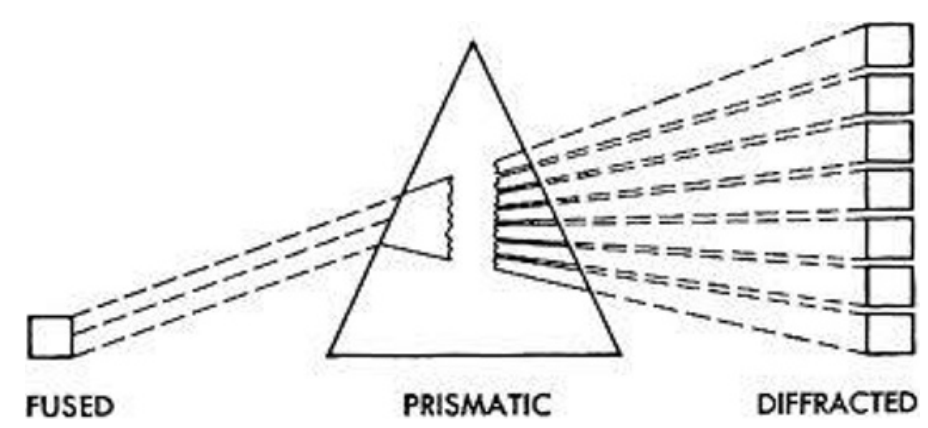

Fig. 1. Prismatic Community by Fred W. Riggs

In evaluating the program, this research uses the concept of The Public Value Strategic Triangle created by Mark Moore as the primary framework to analyse the implementation of Village-Owned State Enterprises program strategically [6]. It has three major elements:

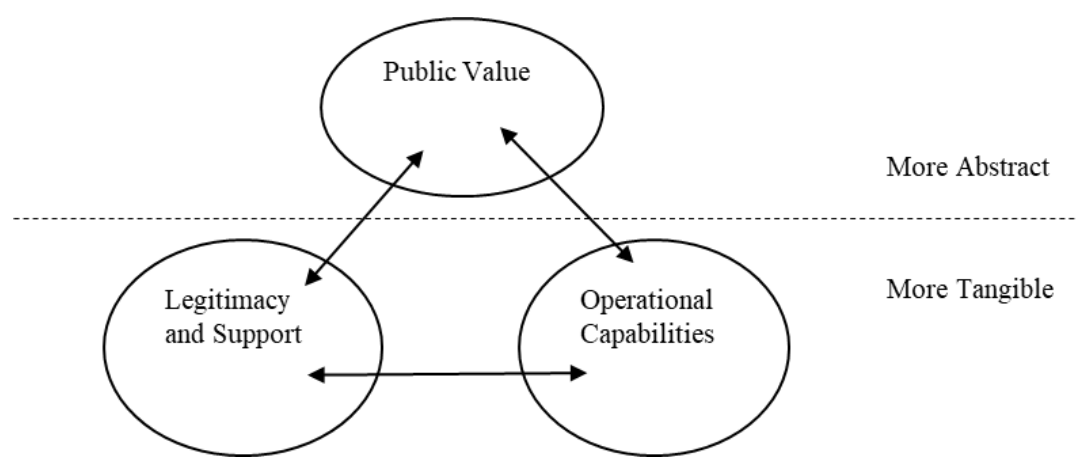

Fig. 2. Strategic Triangle in Creating Public Sector Triangle:

1) Public Value 
Specifically, public value can be produced through several ways [6]:

a. Increasing the quantity of public activities per resource expended;

b. Reducing the cost (in terms of money and authority) used to achieve current levels of production;

c. Making public organization better able to identify and respond to citizen's aspirations;

d. Enhancing the fairness which public sector organizations operate;

e. Increasing their continuing capacity to respond and innovative

2) Legitimacy and Support

The program also needs to have sufficient level of authorizing environment form the actors related, in the form of approval and support. Without this, even the program is ready to create value and have the resources available, the program implementation process will be hindered.

3) Operational Capabilities

This section will analyze the implementation of this program and the obstacle in technical process and capacity.

\section{Objective of the Study}

This study aims at identifying opportunities to maximize Village-Owned State Enterprises impacts by analyzing three elements of its strategic environment which are: public value, legitimacy and support, and operational capabilities.

\section{Methodology}

This research uses sociological juridical research with qualitative approach. The sociological juridical method is used to produce policy analysis as well as to examine the legal culture that exists within society in responding to government policies and forms of participatory community legal development culture in the establishment of Village-Owned State Enterprises in Banyumas.

\section{Discussion}

This research will focus on identifying practices that will optimize the Village-Owned State Enterprises impact based on three elements in the public sector strategic triangle framework [6]. These elements are public value, legitimacy and support, as well as operational capabilities.

\subsection{Public Value}

From around 300 villages in Banyumas, 170 Village-Owned State Enterprises have been successfully established. To effectively optimize the impact of Village-Owned State Enterprises, first, we have to identify the public value that this program tries to achieve in the first place. The intended public value in this analysis will be treated as the primary driver and foundation for horizontal and vertical collaboration between government in supra level and community in village level. From the analysis, there is a contradiction between spirit that envisioned under the village law UU Number. 6 of 2014 and paternalistic approach in the utilization. However, Village-Owned State Enterprises program after the Village Law era, tried to build rural entrepreneurship to realize an independent village movement. Indonesia copied one of the village development strategies in Thailand and Japan called one village one product. With approximately 74,000 villages in Indonesia, the government envisions of having at least 74,000 business products that support and complement each other between 
villages. The sub program is the village zones flagship commodities program. This program contain detail elements of a central-planning economy, where each zone is assigned with a single flagship commodity. This approach intervenes market mechanism where village could specialize or diversify based on supply and demand. While decision on commodity assignments is claimed to be based on rigorous analysis. It is possible to raise slippery slope condition toward large-scale central planning that bring more harm than good like the disastrous village program on Tanzania [7]. While the business results of Village-Owned State Enterprises are expected to sustain all the financing needed by the village so that the village dependence on supra-village will be reduced. The government burden on village communities will also be reduced. Unfortunately this hasn't happened. The portion of funds for physical development still dominates. Only a small portion invested in the Village-Owned State Enterprises. With the pattern of the village community, traditional management is still less effective. Villagers tend to think short-term, so they tend to support Village-Owned State Enterprises that provide direct benefits to them such as infrastructure development, water management, and have not been moved to invest in productive activities.

\subsection{Legitimacy and Support}

This section will analyze the legitimacy and support at the national dan sub-national levels to implement the Village-Owned State Enterprises Program, and how to build the proper legal culture in the community to raise participation and optimized the program. The analyse will focus on legitimacy and support in regards with stakeholders relevant to the implementation process that provide and require legitimacy and support toward one another as influence how the Village-Owned State Enterprises will runs.

a. National Level

Research has identified how low institutional capacity as one of the primary issues that hinder the efficient management in decentralization process [8]. In order to accelerate and streamline village development through Village-Owned State Enterprises, it is necessary to encourage the optimization of the role of Central Government to take the role to providing public services, directing, facilitating development activities, and providing more opportunities to the public and the private sector in the implementation of development. The government can develop detailed village development priorities that can be a guide at the sub-national level. Also the government cooperates with the private sector to providing private services and a trigger of regional economic growth.

b. Subnational Level

In the process of developing Village-Owned State Enterprises, a participatory process is still an indispensable instrument to prevent elite capture and corruption. Making transparency a requirement provides better accountability ensures that the fund resulted from the Village-Owned State Enterprises will accountably managed to the community. Therefore, there is a need to find the productive balance between top-down-directive and bottom-up consultation, which is also central debate in all democratic process.

To realize this, a complete set of regulations is needed related to the management and supervision of Village-Owned State Enterprises in the regional environment. The formation of Village-Owned State Enterprises in Banyumas Regency is still hampered by local regulations. Banyumas does not yet have a Regional Regulation related to VillageOwned State Enterprises so the Village still does not have a strong legal standing if the village wants to create a Village Regulation related to the establishment of VillageOwned State Enterprises in the village. This makes legitimacy and support related to the formation and management of Village-Owned State Enterprises in the villages still hampered. Although, in fact, in the old regulation, the Regional Regulation No. 18 of 2006, Village-Owned State Enterprises has been explained. However, this regulation 
must be immediately amended or adjusted, because there is already Law No. 6 of 2014 concerning Villages. The formation of Village-Owned State Enterprises as mandated by the law has not been widely responded to by the village government, because from the historical and philosophical aspects, it is different from one village to another. The village originally born from the habits or customs that developed in the community, then stood autonomously. Unlike the local government, from the beginning it has become a governmental stretch, so that the regional governments, with a paternalistic approach, have a role to support the management of Village-Owned State Enterprises which participates by:

1. Making the Regional Regulation and the accompaniment of other regulations at the village level.

2. The improvement of Village-Owned State Enterprises economic institutions that have formal legality, including the selection of directors and determination of authorized capital as community-based village-owned enterprises.

3. Arrangement of the form and structure of community association organizations and village-based village-owned enterprises through the village deliberation process;

4. Making the standard operating procedures (SOP) services.

c. Village level

The community is expected to be the main actor in the development process, especially in the development and strengthening of Village-Owned State Enterprises institutions so that their roles are optimal. There are four principles of village governance that must be realized: democracy, participation, transparency and accountability. These four principles contribute to community development including development in the management of Village-Owned State Enterprises.

Village Owned Enterprises which the Central Government continues to intensify in improving the welfare of rural communities, will be managed by operational implementers. As for the village government, become a constructor or supervisor. Later the wealth of the village government and Village-Owned State Enterprises will also be separated. Although both village wealth, the placing is separated. Because VillageOwned State Enterprises are separated from village government organizations so they must be managed on their own since those who handle the people are appointed. The village side only accompanies. The management will be formed as managers and operational implementers. And that operational implementer will later run and control Village-Owned State Enterprises to be more developed. As for the management of results, it is carried out with a profit sharing system. The system will be divided between the village government and a third party or manager, with a percentage of 40-60 percent.

The results obtained by Village-Owned State Enterprises can later be used for village development, helping the poor, as well as village community development. He said, in its development Village-Owned State Enterprises could also hold other parties or other types of businesses as long as it was profitable and prioritized for the interests of the village community.

The problems faced in the management of Village-Owned State Enterprises in Banyumas are:
1) Communication
2) Community access
3) Transparency and accountability
4) Managerial capacity
5) Infrastructure, success and optimization of facilities
6) Access to resources
7) Legal standing 


\subsection{Operational Capability}

The disparity in village caused several complications in the process. Thus it is important to build operational capabilities, specifically on how to build the capacity of local community people that become Village-Owned State Enterprises managerial and the supervisory system.

This can be realized by:

1. Maximalizing the village facilitators

2. Monitoring and evaluating regularly from internal institution inside the village like BPD or regency level which is inspectorate.

3. Giving a regular empowerment from periodical training from government and private actors to the management, related to the issues.

\section{Conclusion}

From the analysis of this paper, it can be concluded that the Village-Owned State Enterprises in Banyumas are still not optimal because of constraints in terms of the rules at the implementation level which are still less supportive of legal certainty, inferiority of the village community legal culture, low managerial capacity, poor quality of resources, inadequate facilities and infrastructure. Suggestions: 1. It is necessary to optimize the role of assistance to villages in developing rules and management patterns of Village-Owned State Enterprises. 2. It is necessary to optimize the deliberation process of the village deliberations so that the legal culture of the village community is more developed and the participation of the community is more active.

\section{References}

1. L. M. Friedman, The Legal System: A Social Science Perspective (Russel Sage Foundation, New York, 1986)

2. L. M. Friedman, Law and Society, an Introduction (Prentice Hall, Inc, New Jersey, 1997)

3. F. Fukuyama, The Great Disruption: Hakikat Manusia dan Rekonstruksi Tatanan Sosial (Indonesian Version, Translation: Ruslani) (Qalam Publishing, Yogyakarta, 1999)

4. S. Rahardjo, Membangun dan Merombak Hukum Indonesia Sebuah Pendekatan Lintas Disiplin (Genta Publishing, Yogyakarta, 2009)

5. F. W. Riggs, Administrasi Negara-Negara Berkembang: Teori Masyarakat Prismatik (Indonesian Version, Translation: Yasogoma) (Rajawali Publishing, Jakarta, 1988)

6. M. H. Moore, Creating Public Value: Strategic Management in Government (Harvard University, Cambrigde, 1995)

7. J. C. Scott, Seeing Like a State (Yale University Press, Connecticut, 1998)

8. Sepulvida, M. Vazquez, "The Concequences of Fiscal Decentralization on Poverty and Income Quality”, International Center for Public Policy Working Paper Series, at AYSPS, GSU (2010) 